\title{
Rancang Bangun Sistem Informasi Ticketing Helpdesk pada DPMPTS Pemprov DKI Jakarta
}

\author{
Alfian$^{1}$, Yumi Novita Dewi ${ }^{2, *}$, Firstianty Wahyuhening Fibriany ${ }^{1}$, Harsih Rianto ${ }^{1}$, Adika May Sari ${ }^{1}$ \\ ${ }^{1}$ Program Studi Sistem Informasi, Universitas Bina Sarana Informatika, Jakarta, Indonesia \\ ${ }^{2}$ Program Studi Sistem Informasi, Sekolah Tinggi Manajemen Informatika dan Komputer Nusa Mandiri, Jakarta, Indonesia \\ Email: 1tivanvian470@ gmail.com ${ }^{2, *}$ yumi.ymd@ nusamandiri.ac.id \\ Email Penulis Korespondensi: yumi.ymd@nusamandiri.ac.id \\ Submitted 15-04-2020; Accepted 25-04-2020; Published 26-04-2020
}

\begin{abstract}
Abstrak
Pelaksana Teknologi dan Informasi Kearsipan (PSTIK) adalah bidang yang mempunyai tugas pokok membantu kepala dinas dalam memimpin dan melaksanakan tugas pengelolaan teknologi informasi dan komunikasi. PSTIK saat ini belum terkomputerisasi dan hanya mengandalkan whatsapp atau koneksi via telpon untuk menyampaikan permasalahan hardware, software ataupun jaringan internet yang disebut istilah Ticketing Helpdesk. Aplikasi ini memungkinkan pada saat proses persetujuan dan pengerjaan tidak terjadi kesalahan dalam komunikasi pada DPMPTS Pemprov DKI Jakarta. Dengan sistem informasi Ticketing Helpdesk ini diharapkan dapat membantu kegiatan operasional sehingga menunjang proses bisnis pada bidang PSTIK agar lebih baik dibandingkan dengan sistem sebelumnya.
\end{abstract}

Kata Kunci: Sistem Informasi, Ticketing Helpdesk, Software Helpdesk

\section{Abstract}

Implementing Information Technology and Archiving (PSTIK) is a field that has the main task of helping the head of service in leading and carrying out the task of managing information and communication technology. PSTIK is currently not computerized and only relies on whatsapp or telephone connections to address hardware, software or internet network issues called Ticketing Helpdesk. This application allows that at the time of the approval and processing process there is no error in communication at the DPMPTS of the DKI Jakarta Provincial Government. With this Ticketing Helpdesk information system, it is expected to be able to assist operational activities so as to support business processes in the PSTIK sector to be better than the previous system.

Keywords: Information System, Ticketing Helpdesk, Software Helpdesk

\section{PENDAHULUAN}

Pelaksana Teknologi dan Informasi Kearsipan (PSTIK) adalah bidang yang mempunyai tugas pokok membantu kepala dinas dalam memimpin dan melaksanakan tugas pengelolaan teknologi informasi dan komunikasi. Di PSTIK banyak macam berbagai aplikasi sistem berbasis web dan jarang sekali yang memakai manual, seperti sistem monitoring, sistem pelayanan, sistem perizinan lain sebagainya. Akan tetapi pada bagian komunikasi antar kota ke dinas, kecamatan ke dinas dan kelurahan ke dinas masih terdapat kendala dimana belum adanya sistem informasi yang mendukung untuk proses bisnisnya.

Dengan semakin meningkatnya kebutuhan informasi menyebabkan penggunaan teknologi informasi dan komunikasi semakin dibutuhkan untuk pengelolaan informasi yang cepat dan menghasilkan informasi yang benar bagi yang membutuhkannya[1]. Hal ini memungkinkan kemudahan serta solusi terbaik untuk perbaikan otomatisasi sistem yang semulanya masih manual, dimana menggunakan Whatsapp dan Telepon.

Menggunakan sistem informasi untuk mengkombinasikan antara prosedur kerja, informasi, orang dan teknologi informasi yang diorganisasikan untuk mencapai sebuah tujuan dalam organisasi[2]. Tuntutan pelayanan informasi dan pengelolaan informasi secara terintegrasi menjadi sangat penting di setiap lembaga, termasuk di lingkungan Dinas Penanaman Modal Pelayanan Terpadu Satu Pintu (DPMPTSP) wilayah DKI Jakarta.

Aplikasi Ticketing Helpdesk adalah aplikasi yang yang dibangun untuk memudahkan management dalam menyampaikan keluhan berkaitan dengan kerusakan penggunaaan perangkat keras dan perangkat lunak yang ada dilingkungan DPMPTSP wilayah DKI Jakarta, serta dilengkapi dengan model approval dan laporan status pengerjaan dari pihak PSTIK. Dengan demikian pengadaan sistem ini sangat mempengaruhi keefektifitas management dalam menyelesaikan proses.

\section{METODE PENELITIAN}

\subsection{Objek Penelitian}

Adapun objek penelitian ini adalah Dinas Penanaman Modal Pelayanan Terpadu Satu Pintu (DPMPTSP) wilayah DKI Jakarta. Dimana Gagasan Guberur DKI pada tahun 2015 supaya Pemeritah Propinsi DKI memiliki pelayanan yang terpadu dan hanya satu pintu untuk melayani kebutuhan masyarakat luas. Gagasan ini kemudian diimplementasikan secara nyata oleh Gubernur DKI Jakarta selanjutnya. Dengan dibentuknya Badan Pelayanan Terpadu Satu Pintu (BPTSP) dimana satuan kerja perangkat daerah dibentuk berdasarkan Peraturan Daerah Nomor 12 Tahun 2013 tentang penyelenggaraan Pelayanan Terpadu Satu Pintu. Satuan kerja ini memiliki tugas untuk melayani perizinan dan non perizinan dengan sistem satu pintu. Pada tahun 2017 Badan Pelayanan Terpadu Satu Pintu berubah nama menjadi Dinas Penanaman Modal dan Pelayanan Terpadu Satu Pintu. 


\subsection{Sistem}

Sistem menurut McLeod dalam Ramanda adalah sekelompok elemen yang terintegrasi dengan maksud yang sama untuk mencapai suatu tujuan[3]. Sistem merupakan suatu komponen atau variabel yang terorganisir, saling berinteraksi, saling bergantung, satu sama lain dan terpadu[3]. Sistem informasi mempertemukan kebutuhan pengolahan transaksi harian, mendukung operasi, yang bersifat manajerial dan kegiatan strategis dari suatu organisasi dan menediakan bentuk-bentuk laporan terhadap pihak luar[4]. Dengan menggunakan sistem yang tepat guna maka kegiatan-kegiatan yang selalu berulang dapat digantikan menggunakan komputer.

\subsection{Helpdesk}

Helpdesk merupakan bagian atau divisi dalam organsisasi yang menyediakan dukungan kepada pengguna produk, layanan dan teknologi[5]. Jadi helpdesk merupakan bagian dari perusahaan yang menyediakan dokumen fungsi produk, servis atau teknologi dari perusahaan tersebut. Helpdesk yang melayani atau menanggapi pertanyaan teknis dari pengguna. Helpdesk juga digunakan untuk menjawab pertanyaan client[6]. Pertanyaan dan jawaban dapat disampaikan melalui telepon, email, web atau fax. Bahkan ada software helpdesk yang membuat orang lebih mudah untuk menjalankan helpdesk dengan cepat untuk menemukan jawaban yang bersifat umum[7]. Perkembangan helpdesk saat ini makin dilihat sebagai satu kesatuan dengan fungsi layanan dan bertanggung jawab untuk menjembatani sumber daya untuk menyelesaikan masalah dan memenuhi kepuasan user[8].

\subsection{Tiketing}

Ticketing adalah sebuah karcis gangguan (atau disebut juga laporan masalah) yang digunakan dalam suatu organisasi untuk melacak deteksi, pelaporan, dan resolusi dari beberapa masalah[9]. Sistem ticketing helpdesk adalah suatu sistem yang terorganisasi dari sebuah karcis gangguan yang dilaporkan dari pengguna ke tim pendukung untuk menyelesaikan masalah yang ada dipengguna dan sebagai pelengkap dari sebuah fungsi pelayanan. Dalam perkembangkan sistem ticketing saat ini sudah menggunakan aplikasi berbasis web untuk mendukung manajemen pelangan seperti call center.

\section{HASIL DAN PEMBAHASAN}

\subsection{Metode Pengembangan Sistem}

Pada penelitian ini pengembangan perangkat lunak menggunakan metode prototype. Prototype adalah model pengembangan perangkat lunak dengan yang diawali dengan pengumpulan kebutuhan-kebutuhan dari sistem, yang dilanjutkan dengan pembuatan prototype dan evaluasi dari pengguna[10]. Metode prototype adalah model SDLC yang paling sederhana, model ini menggambarkan kebutuhan maupun spesifikasi yang diinginkan oleh user kepada pengembang sistem[11], artinya model pengembangan prototype ini mampu memberikan gambaran kebutuhan sistem ticketing helpdesk yang akan dibangun[2].

Sistem ticketing helpdesk dibangun dengan model berbasis web yang memungkinkan client, kasatpel dan teknisi dapat berinteraksi langsung dengan dihadapkan sebuah aplikasi. Adapun skema perancangan sistem ticketing helpdesk ini dibagi menjadi 2 bagian berdasarkan pengguna sistem, yaitu:

a. Kebutuhan Halaman Front-end.

Pada halaman front-end yang dapat diakses oleh client terdapa menu-menu sebagai berikut:

1. Client dapat menginput ticket baru.

2. Client dapat menginput subjek dan deskripsi masalah.

3. Client dapat melihat ticket.

4. Client dapat memberikan feedback kepada teknisi.

b. Kebutuhan Halaman Back-End.

Pada halaman Back-end yang dapat diakses oleh administrator, kasatpel dan teknisi terdapa menu-menu sebagai berikut:

1. Login untuk masuk keruang home.

2. Kasatpel dapat melihat ticket yang masuk.

3. Kasatpel dapat melihat menyetujui tick

4. Kasatpel dapat memberikan tugas kepada teknisi.

5. Kasatpel dapat melihat laporan teknisi.

6. Teknisi dapat melihat ticket.

7. Teknisi dapat menginput solusi ticket.

8. Teknisi dapat menyelesaikan ticket.

\subsection{Perancangan Sistem Usulan}

Berikut Gambar 1 diagram use case yang merupakan rancangan usulan ticketing helpdesk. 


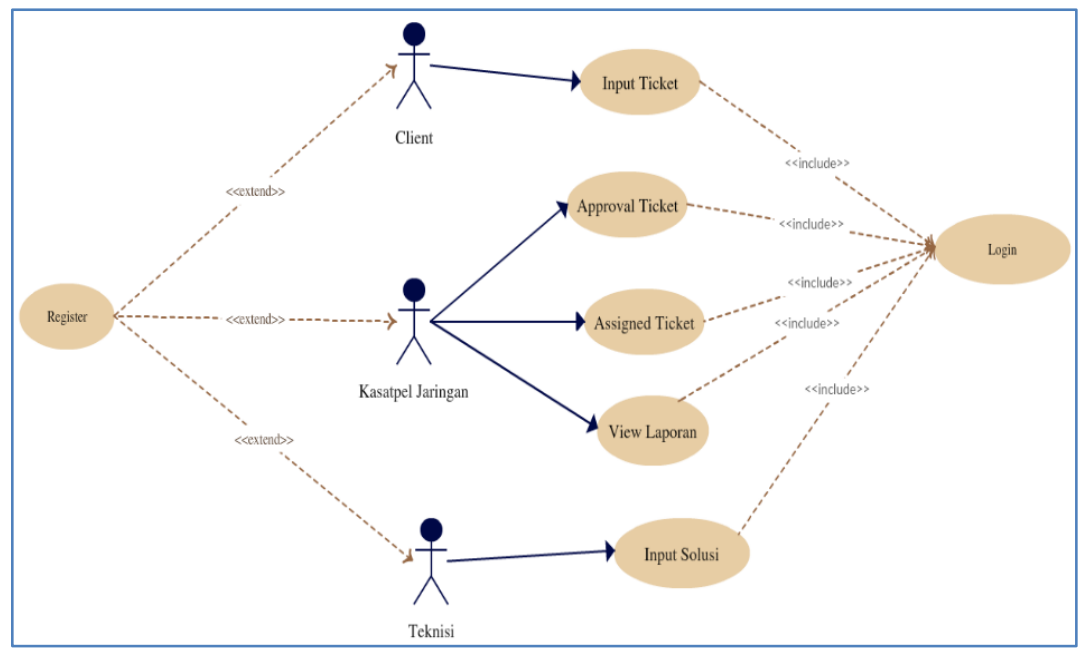

Gambar 1. Use Case Diagram Perancangan Sistem Usulan

Dimana use case tersebut dapat dideskripsikan sebagai berikut:

Tabel 1. Deskripsi Use Case

\begin{tabular}{|c|c|c|c|}
\hline No & Use case & Deskripsi & $\begin{array}{l}\text { Pelaku yang } \\
\text { Berpartisipasi }\end{array}$ \\
\hline 1 & Register & $\begin{array}{l}\text { Usecase menggambarkan kegiatan registrasi Client ke dalam } \\
\text { sistem untuk memperoleh account. }\end{array}$ & Client \\
\hline 2 & Login & $\begin{array}{l}\text { Usecase menggambarkan kegiatan login kedalam sistem dengan } \\
\text { memasukkan data pengguna untuk diverifikasi oleh sistem. }\end{array}$ & $\begin{array}{l}\text { Client, tim support, } \\
\text { Kasatpel Jaringan }\end{array}$ \\
\hline 3 & Input Ticket & Usecase menggambarkan kegiatan memasukkan data ticket. & Client \\
\hline 4 & $\begin{array}{l}\text { Approval } \\
\text { Ticket }\end{array}$ & Usecase menggambarkan kegiatan menyetujui data ticket. & Kasatpel Jaringan \\
\hline 5 & $\begin{array}{l}\text { Assigned } \\
\text { Ticket }\end{array}$ & $\begin{array}{l}\text { Usecase menggambarkan kegiatan menugaskan teknisi untuk } \\
\text { menyelesaikan masalah atau ticket. }\end{array}$ & Helpdesk \\
\hline 6 & Input Solusi & $\begin{array}{l}\text { Usecase menggambarkan kegiatan memasukkan data solusi atau } \\
\text { penyelesaian terhadap ticket kedalam sistem. }\end{array}$ & Tim support \\
\hline 7 & $\begin{array}{l}\text { Lihat } \\
\text { Laporan }\end{array}$ & Usecase menggambarkan kegiatan melihat laporan ticket. & Kasatpel Jaringan \\
\hline
\end{tabular}

Pada dasarnya, unit kerja ticketing helpdesk terdiri dari 2 tim frontdesk dan tim support. Sistem ticketing helpdesk mengelola dua tugas yaitu pencatatan dan penyelesaian masalah pada unit yang terkait dan menyediakan laporan seperti terlihat pada Gambar 2 dibawah ini. Alur kerja dari sistem ticketing dimulai dari proses laporan client yang mengalami masalah dan kendala. Tim support akan mencatat keluhan dari client, kemudian menyampaikan pada Kasupel jaringan untuk mendapatkan solusi dari permasalahan client. Setelah mendapatkan solusi tim support akan memeritahukan pada client kembali.

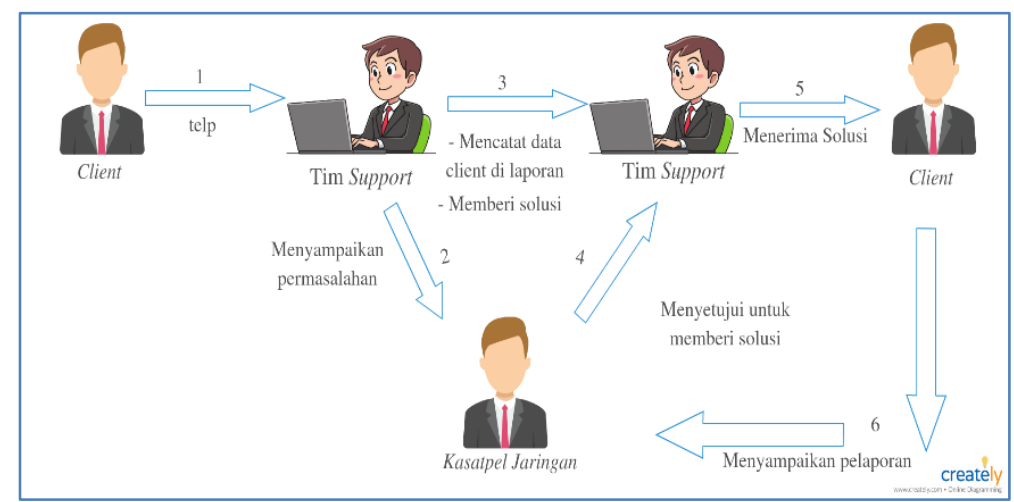

Gambar 2. Bagan Prosedur Sistem Berjalan

Usulan rancangan sistem dibangun dengan menambahkan sort by tanggal dilaporan dan dapat melihat laporan perminggu, perbulan, dan pertahun. Dimana untuk awal penggunaan sistem ticketing helpdesk ini user yaitu client, teknisi dan kasatpel harus terlebih dahulu melakukan login dengan memasukkan username dan password yang valid. Berikut bentuk tampilan 


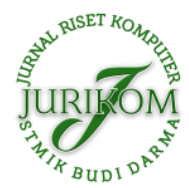

antar muka pada menu login terlhat pada Gambar 3.

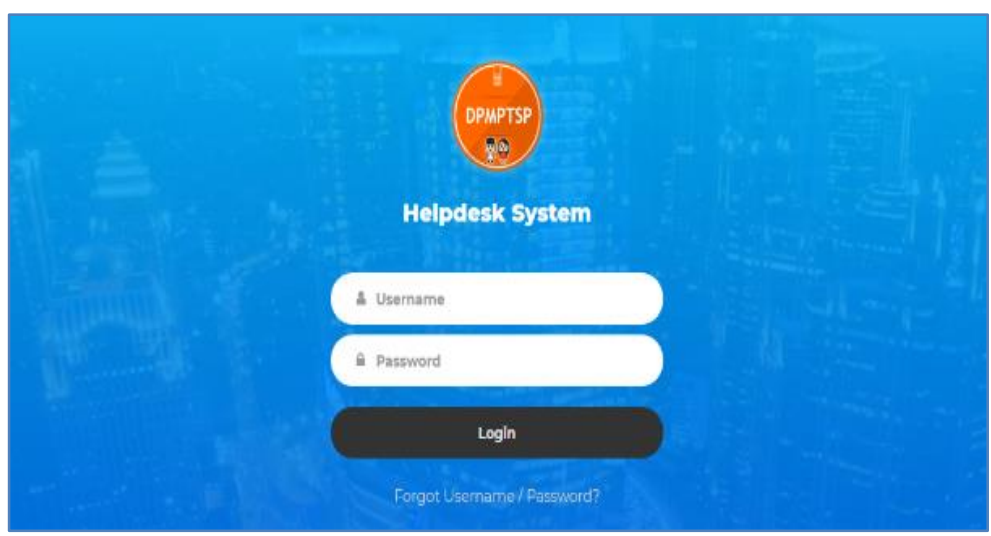

Gambar 3. Menu Login

Selanjutnya kasatpel memilih menu list ticket dan sistem akan menampilkan halaman list ticket dan id ticket seperti Gambar 4. Untuk melakukan proses assign ticket ke teknisi, kasatpel akan memilih teknisi untuk menyelesaikan ticket tersebut sesuai dengan wilayah yang dikerjakan oleh teknisi. Sistem akan menyimpan data assigned ticket dan sistem akan menampilkan halaman list ticket.

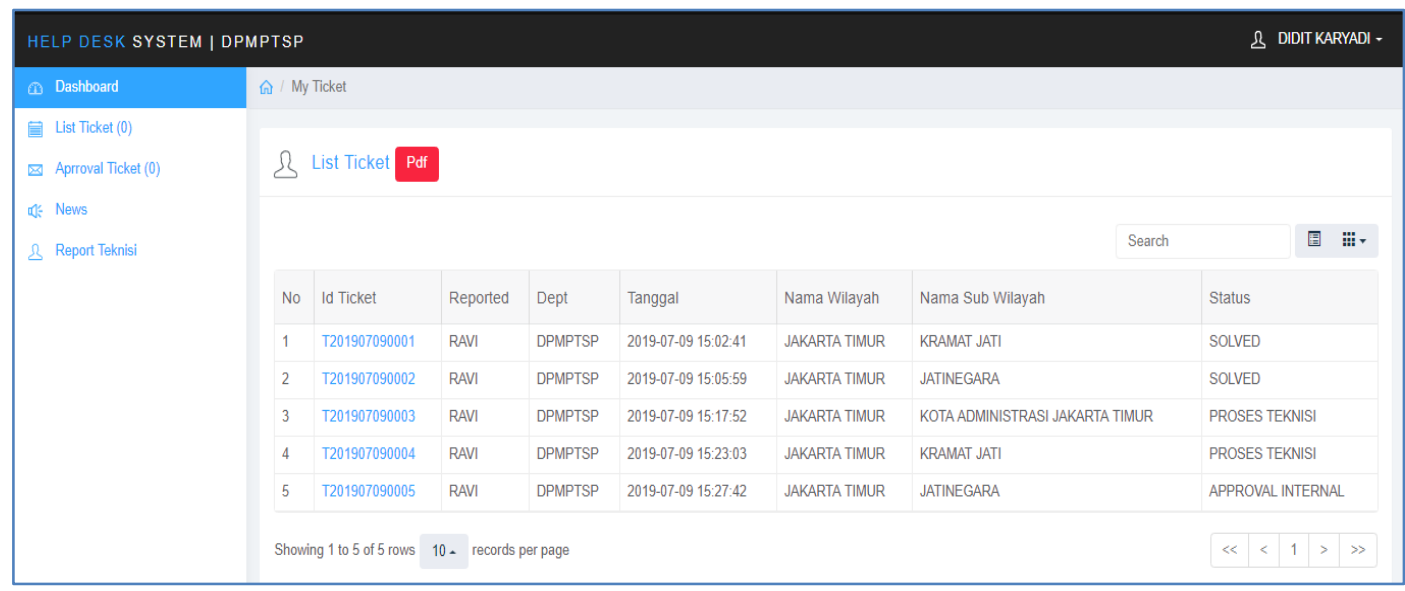

Gambar 4. Tampilan List Ticket

Proses selanjutnya teknisi dan kasatpel dapat melakukan tracking terhadap tiket yang sudah dibuat, melihat progress prosentase pekerjaan yang sudah diselesaikan oleh teknisi. Gambar 5 merupakan tampilan tracking tiket berdasarkan id tiket yang sudah dipilih. Proses selanjutnya jika pekerjaan yang dikalukan oleh teknisi selesai makan pada id tiket yang sudah dipilih dapat dilakukan approval. Tampilan pada Gambar 6 adalah proses approval terhadap tiket yang sudah selesai sepenuhnya dan dikerjakan oleh teknisi. Setelah proses approvel dilakukan maka sistem akan mencatat seluruh kejadian yang dilakukan oleh teknisi seperti deskripsi solusi yang sudah dilakukan, catatan dari client dan kendala yang dihadapi selama menyelesaikan proses pekerjaan.

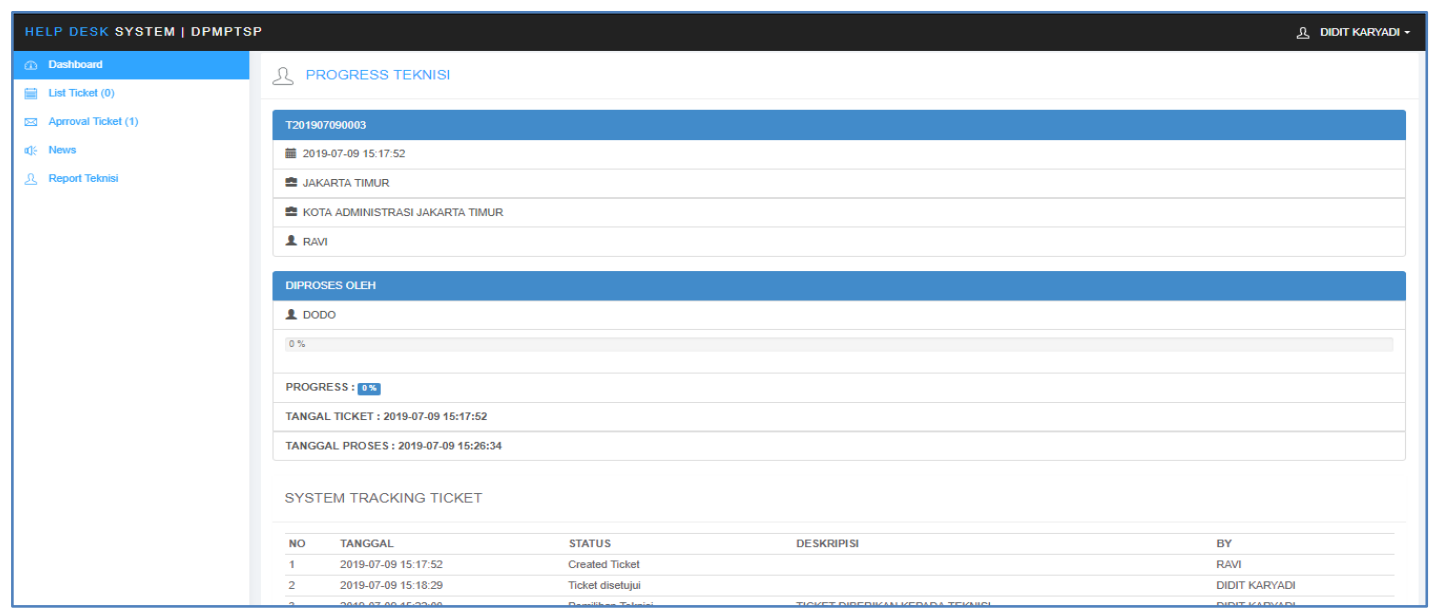

Gambar 5. Tampilan Tracking Ticket 


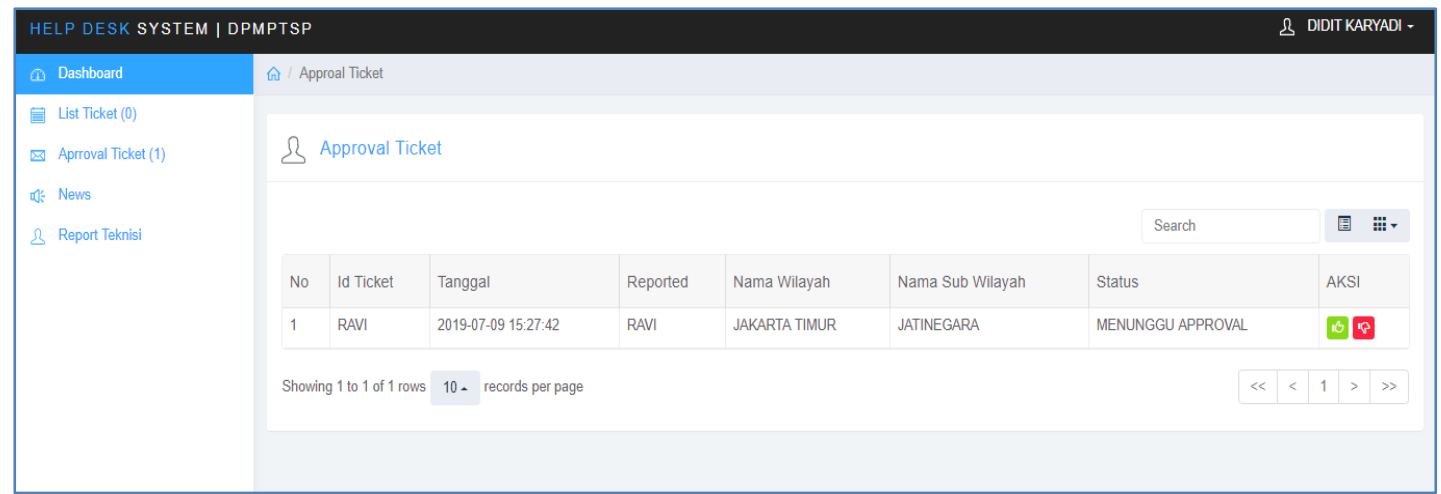

Gambar 6. Tampilan Approval Ticket

Proses selanjutnya kasatpel dapat melakukan tracking terhadap perkerjaan teknisi dalam menyelesaikan tiket yang sudah dibuat. Gambar 8 merupakan tampilan laporan performance teknisi dalam menyelesaikan tiket yang sudah masuk list tiket. Dengan melihat laporan progress ini kasatpel dapat menilai hasil pekerjaan teknisi secara lebih cepat.

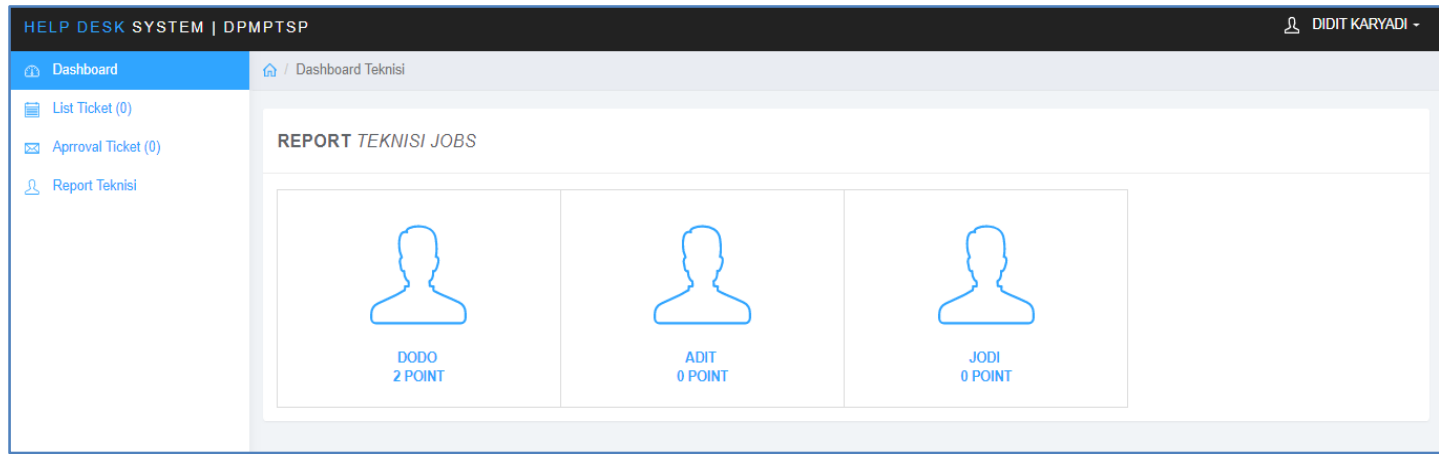

Gambar 7. Tampilan Report Teknisi

\subsection{Entiy Relationship Diagram (ERD)}

ERD menggambarkan hubungan antara satu entitas yang memiliki sejumlah atribut dengan entitas yang lain dalam suatu sistem yang terintegrasi. Pada Gambar 8 menujukan rancangan ERD yang dibuat untuk sistem ticketing. Dimana pada sistem ticketing helpdesk terdapat lima entitas yang saling terhubung dengan relasinya.

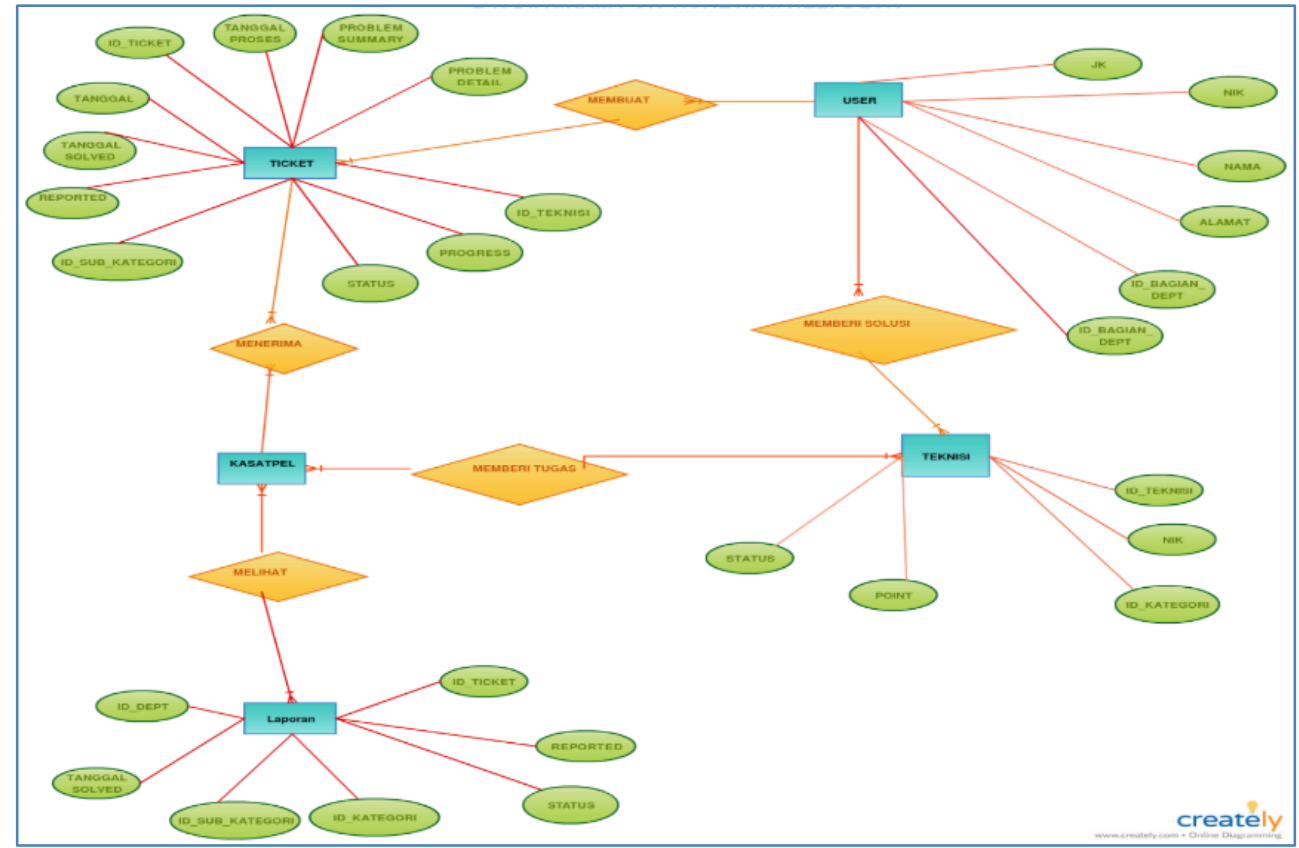

Gambar 8. Rancangan ERD

Pemodelan data pada ERD ini nantinya akan dikembangkan menjadi database pada sistem ticketing helpdesk 


\subsection{Logical Record Structure (LRS)}

Hasil rancangan ERD pada gambar 8 kemudian di transformasikan menjadi Logical Record Structur. Pada Gambar 9 merupakan rancangan dari LRS yang akan diimplementasikan pada pembuatan database sistem ticketing heldesk. LRS mepresentasi dari struktur record-record pada tabel-tabel yang terbentuk dari hasil relasi antar himpunan entitas yang ada pada proses sistem ticketing helpdesk.

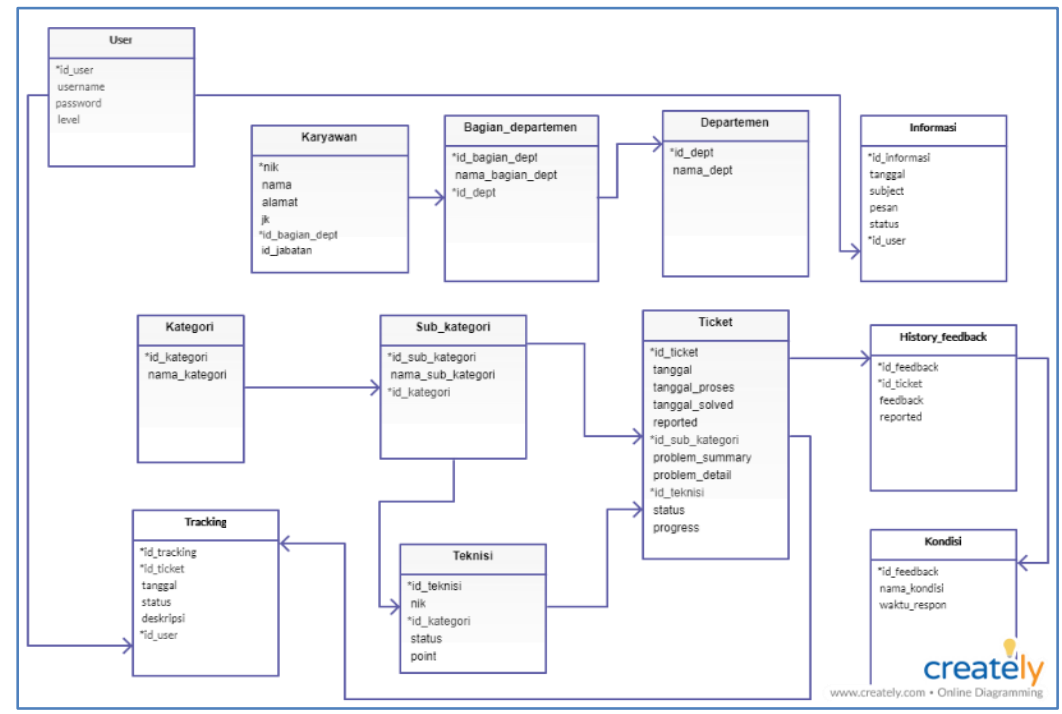

Gambar 9. Rancangan LRS

\subsection{Class Diagram}

Class diagram digunakan untuk menggambarkan struktur sistem dari sisi pendefinisian kelas-kelas yang akan dibangun pada sistem. Pada Gambar 10 memperlihatkan rancangan class diagram untuk sistem ticketing heldesk. Dalam rancangan class diagram sudah ditentukan property apa saja yang akan berpengaruh terhadap jalannya sistem dari masing-masing class yang terbentuk.

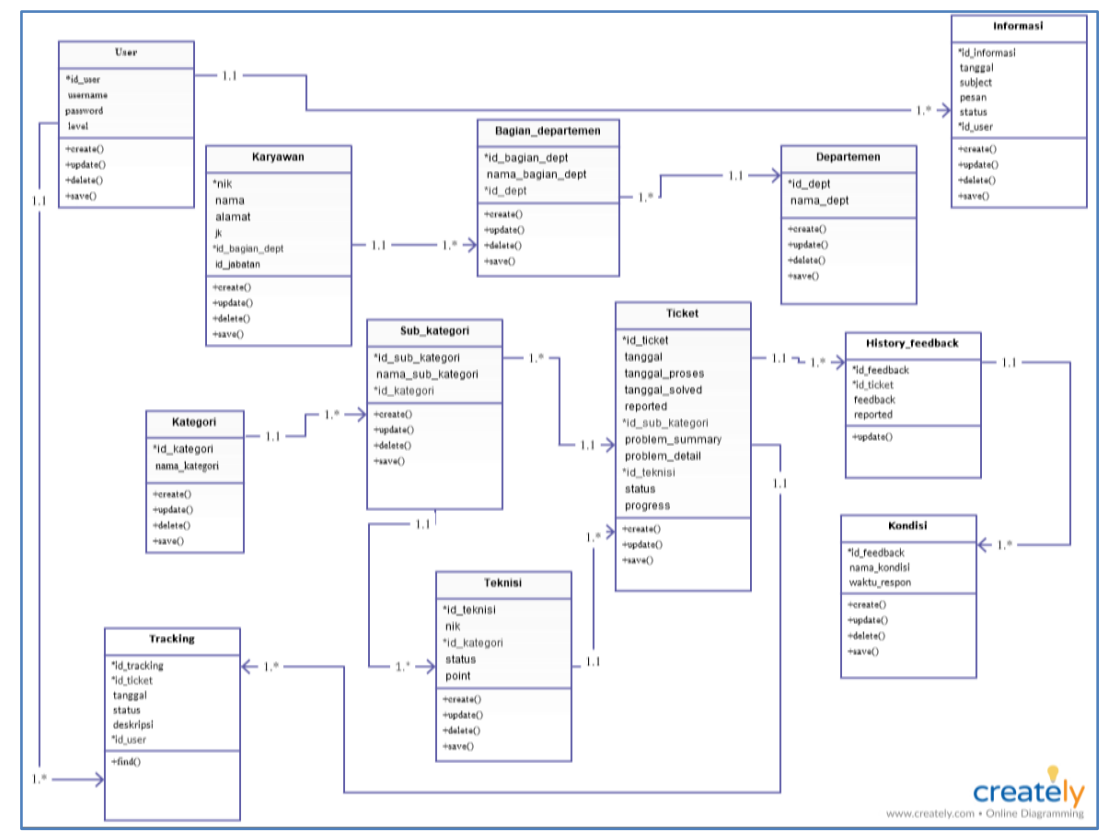

Gambar 10. Class Diagram Ticketing Helpdesk

\section{KESIMPULAN}

Berdasarkan dari uraian dan pembahasan sebelumnya, maka penggunaan Sistem Informasi Pelaksana Teknologi dan Informasi Kearsipan (PSTIK) yang masih dilakukan secara manual akan banyak mengandung resiko pada Ticketing Helpdesk, maka dengan ini dibuatnya sistem informasi Ticketing Helpdesk ini diharapkan dapat membantu kegiatan 
operasional sehingga menunjang proses bisnis pada bidang PSTIK agar lebih baik dibandingkan dengan sistem sebelumnya dan mendapat informasi yang akurat dan tepat.

\section{REFERENCES}

[1] R. Amin, "Sistem Informasi Helpdesk Berbasis Web Pada PT. Sisindokom Lintasbuana Jakarta," in Konferensi Nasional Ilmu Pengetahuan dan Teknologi, 2016, pp. 15-20.

[2] M. R. Fachlevi and R. F. Syafariani, "Perancangan Sistem Informasi Kepegawaian Berbasis Website Di Bagian Kepagawaian Sdn Binakarya I Kabupaten Garut," Simetris J. Tek. Mesin, Elektro dan Ilmu Komput., vol. 8, no. 2, pp. 553-558, 2017.

[3] R. Kresna, "Penerapan Sistem Manajemen Operasional Pelayanan Pemesanan Menu Makanan Dengan Waiting Line Method," J. Pilar Nusa Mandiri, vol. XII, no. 2, pp. 183-189, 2016.

[4] U. Hasanah, "Sistem Informasi Penjualan On_Line Pada Toko Kreatif Suncom Pacitan," IJNS - Indones. J. Netw. Secur., vol. 2, no. 4, pp. 40-48, 2013.

[5] B. Wooten, Building \& managing a world class IT help desk. Berkeley, California: McGraw-Hill Osborne Media, 2001.

[6] R. Rico, “Analisis Dan Perancangan Sistem Informasi It- Helpdesk ( Studi Kasus : Pt . Lontar Papyrus Pulp \& Paper Industry ),” J. Ilm. MEDIA SISFO, vol. 10, no. 2, pp. 296-305, 2016.

[7] L. D. Fitrani and R. V. H. Ginardi, "Analysis Improvement of Helpdesk System Services Based on Framework COBIT 5 and ITIL 3rd Version (Case Study: DSIK Airlangga University)," in The 4th International Seminal on Science and Technology, 2018, vol. 0, no. 1, p. 28.

[8] R. M. Bahrudin, M. Ridwan, and H. S. Darmojo, "Penerapan Helpdesk Ticketing System Dalam Penanganan Keluhan Penggunaan Sistem Informasi Berbasis Web," Jutis, vol. 7, no. 1, pp. 71-82, 2019.

[9] W. D. Suryono, Saptono, Ristu, and W. Wiranto, "Implementasi Pengembangan Smart Helpdesk di UPT TIK UNS Menggunakan Algoritma Naive Bayes Classifier," in Seminar Nasional Aplikasi Teknologi Informasi (SNATi), 2017, pp. $39-43$.

[10] Q. Qoyyimah, N. A. Hidayah, and Z. B. Fananie, "Rancang Bangun Helpdesk Ticketing System ( Studi Kasus : Pt . Primus Indojaya )," Stud. Inform. J. Sist. Inf., vol. 5, no. 1, pp. 1-7, 2012.

[11] R. A.S and M. Shalahuddin, Rekayasa Perangkat Lunak Terstruktur dan Berorientasi Objek. Bandung: Informatika, 2013. 